\title{
A study on the perception of the corruption phenomenon within the Inland Revenue
}

\author{
Maurizio Longhi \\ Dottore in Scienze dell'Amministrazione e della Sicurezza: Organizzazione, Sicurezza e Investigazione, Italy
}

\begin{abstract}
In spite of many national and international studies on the causes of corruption, it is rarely investigated in which terms the criminological theories can provide useful suggestions to better understand the etiology of this form of criminality. The present work aimed to study how the corruption phenomenon is perceived by the employees of the Inland Revenue. The research was conducted on a sample of 50 subjects between 30 and 65 years old. For the purposes of the research, a questionnaire consisting of 19 items was distributed to them. It was significantly found that the subjects did not have problems to respond to general questions, despite particular questions, where instead the sampling found considerable difficulties. Therefore the knowledge is resulted in general terms and not in specific terms. A limitation of this study is that perceptions can rapidly change as a result of political scandals or different cultural settings. The different answers can be influenced by both the quality in the formulation of the application and the little experience of the interviewed subjects. Given the found data we can consider that this study confirms what is already evident in the literature. Corruption is the result of contacts with criminal patterns and the removal from anti-criminal patterns, since each individual assimilates the culture surrounding him.
\end{abstract}

\section{RIASSUNTO}

Nonostante i numerosi studi a livello nazionale e internazionale sulle cause della corruzione sono rari quelli che approfondiscono in che termini le teorie criminologiche possono fornire suggerimenti utili a comprendere meglio l'eziologia di questa forma di criminalità. Il presente lavoro si proponeva di studiare come viene percepito il fenomeno corruttivo da parte dei dipendenti dell'Agenzia delle Entrate. La ricerca è stata condotta su un campione di 50 soggetti tra i 30 e i 65 anni. Ai fini della ricerca è stato distribuito loro un questionario costituito da 19 item. È emerso in modo significativo che, alle domande di carattere generale, i soggetti non hanno avuto problemi a rispondere, a differenza delle domande particolari, dove invece il campione ha riscontrato notevoli difficoltà. La conoscenza quindi è risultata in termini generali e non in termini specifici. Un limite di questo studio è che le percezioni possono cambiare rapidamente a seguito di scandali politici o impostazioni culturali diverse. Le diverse risposte possono essere influenzate sia dalla qualità nella formulazione della domanda sia dalla poca esperienza dei soggetti intervistati. Considerati i dati emersi possiamo ritenere che questo studio conferma ciò che in letteratura già si evince. La corruzione è il risultato di contatti con modelli (pattern) criminali e dall'allontanamento da modelli (pattern) anti-criminali, poiché ogni persona assimila la cultura che la circonda.

\section{RESUMEN}

Son numerosos los estudios realizados a nivel nacional e internacional sobre las causas de la corrupción; no obstante, son muy pocos los que llegan a explicar como las teorias criminológicas pueden proporcionar las pautas necesarias para comprender la etiología de esta forma de criminalidad. Este trabajo se propone analizar como los empleados de la Agenzia delle Entrate perciben el fenómeno de la corrupción. La investigación se ha llevado a cabo sobre un grupo de 50 individuos de entre 30 y 65 años, que han sido sometidos a una encuesta de 19 puntos (item). Los resultados mostraron claramente que mientras los participantes no han tenido problemas en contestar a preguntas de carácter general, si han tenido muchas dificultades con respecto a las preguntas más específicas. Sus conocimientos sobre el fenómeno pueden entonces definirse generales y no específicos. La limitación de este estudio radica en el simple hecho de tener distintas concepciones culturales y que las percepciones del fenómeno pueden cambiar rápidamente a consecuencia de escándalos políticos. Las respuestas pueden además verse afectadas por la manera de formulación de las mismas preguntas y por la poca experiencia de los sujetos analizados con el fenómeno. En conclusión, los datos procedentes de este estudio confirman lo que la literatura del sector mostraba ya claramente. La corrupción es el resultado del contacto con patrones criminales y de la lejanía de los anticriminales, ya que cada persona asimila la cultura que le rodea.

\section{Introduction}

The Penal Code, in articles 318 and ff. defines the crime of corruption as an agreement between a private individual and a public official as a result of which the latter accepts from the former a fee not due for the accomplishment of an act of his "office activities". The legal object protected by this matter is the fair and impartial activity of the Public Administration, whose image and respectability are damaged as a consequence of the unlawful agreement. Both the corrupt and the private corrupter respond to the crime of corruption. Therefore, there is a joint negligence of both parties in committing the crime and in punishment.

Despite numerous national and international studies, only few examine in depth if and in what terms the criminological theories can provide useful ideas to better understand the etiology of this form of crime. The scientific debate on the causes of corruption is 
very wide. In simple terms, we can say that the different theories are placed on the following positions:

1. corruption originates from dysfunction of social and political systems (Benson et al., 1978);

2. corruption does not depend on dysfunction but on economic, social or political variables. (Merton, 1972; Scott, 1972; Nye, 1967; Rose-Ackerman, 1978).

As it is well know, in the early Nineties the judicial inquiry called "clean hands" brought to light an extended system of widespread corruption in the political and financial world, based on stable agreements that ensured a constant flow of loans to the parties by the companies in contact with public administrations for the provision of works and services through the payment of bribes.

As far as the number and the top position of the involved subjects (above all politicians and bureaucrats, military, magistrates) this wide and deep investigation had relevant consequences on the political and institutional structure with main political parties leaving the scene and the emerging of new political groups which started the so-called "second republic". Therefore, the corruption needed an organization in order to become a system, since corrupt and corrupter established a stable and lasting structure to manage illicit transactions, used specific tools (false budgets, black funds, etc.) aimed to regular and structured financial plans (Di Nicola, 2003). Probably this situation came out (Savona and Mezzanotte, 1998) because corruption was now considered an insurmountable limit for the public debit that could not expand beyond also for external conditions, such as the membership in the European Union and the deriving obligations. Moreover, it was highlighted that, unlike what happened to face other criminal emergencies - from terrorism to organized crime - for corruption it was not decided to adopt special law which would strengthen the instruments of investigation and coercion, allowing criminal justice to effectively face a system of widespread lawlessness. Thus, when the wave of popular consensus to the action of the judges - crucial in supporting the most incisive steps of the investigation - has passed, in the years that follow the story of tangentopoli there was in our country a certain "reductivism" towards the phenomenon of corruption consisting in the tendency to underestimate its gravity, to limit its economic scope to the patrimonial aspect of the bribe, to the illicit exchange between the corrupt and the corrupter, neglecting the actual consequent damage. This happens while in literature, especially on an international level, the various economic, institutional and social effects of the corruptive phenomenon were studied, and it is affirmed with increasing force and unanimity that the damage deriving from corruption goes well beyond the dispersion of resources imposed by the bribes to the business world or the additional burdens for public spending.

In Italy, national policies seemed acting as if the risk of corruption was no longer a problem. On the contrary, the recent chronicles render the image of a country in which it is a common practice paying bribes in awarding contracts, obtaining building permits, carrying out financial transactions and also passing university exams and practicing the medical profession (Della Porta and Vannucci, 2007). The picture drawn by the scholars of this matter shows a society manifesting the circular dynamics of a "systemic" corruption and, in the absence of institutional counterweights, this system is self-perpetuated and expanding. As already noted, as much corruption is widespread and practiced, as the risk of being reported or discovered is lower and, consequently, the cost of choosing to remain honest is higher. As the so-called "culture of corruption" gradually spreads, the same moral constraints of condemning corruption tend to be loosened. We can deduce that corruption is considered diffused even after "clean hands" and tends to increase.
Extensive research has been carried out on the "Italian case" which have highlighted environmental conditions favorable to the development and rootedness of corruption - on which no intervening over the years has been carried on - identified in a conception of the State, both at the level of leaders of society and population, propitious to manifesting of subcultures that legitimate the violation of the rules in favor of particularistic groups and in the basic features of the political-institutional set-up. Unfortunately, our system confirms what is highlighted by the research carried out in the international sphere, which considers the corruption related to the degree of regulatory discretion, to the amount of resources administered by the State, to the complexity of laws and regulatory inflation, to the inefficiency of public administration, to the complex bureaucratic system that influences business activities, to the tax burden, to the lack of confidence in the functioning of democracy. Under another profile but in the same line, we have to think that the level of corruption in the country is negatively influenced by the degree of economic freedom, by the quality of the rule of law, by the amount of penalties expected and effectively executed.

The scientific criminological literature shows that researchers try to understand the origins and causes of their different approaches, following four main directions: social, economic, administrative and political. With reference to social causes, particular attention was paid to social / cultural determinants (Karstedt, 2001) and to the way in which intersubjective relationships can affect levels of corruption. For example, researchers have shown a negative association between trust in neighbor and corruption (see La Porta et al., 1997; Adsera et al., 2000), and they found a positive correlation between the trust existing between entrepreneurs in a given country and the perceived levels of corruption (Lambsdorff, 2002).

In the analysis of the economic causes, the competition between companies has become particularly relevant, namely the hypothesis that corruption can be caused by a low level of competition (Henderson, 1999). In this theme, Ades and Di Tella (1999) showed the existence of a negative association between the commercial openness of a country - estimated in terms of the relationship between imports and GDP - and the perceived corruption. Gerring and Thacker (2005) reached similar results. Again in this field, Ades and Di Tella (1995) agree that the decrease in competition corresponds to a general increase in corruption.

On the administrative causes, some authors (Lapalombara, 1994) have tried to correlate the amount of the budget available to national governments with the levels of perceived corruption, following the hypothesis that a growth in the economic availability of the Executive branch could determine an increase in corruption. Otherwise, Elliott (1997) was among the first to pay attention not only on the economic disposition of national governments, but on the different sectors of the national economy where the public hand is more present.

A second group of scientific contributions has examined in depth the connection between devolved government and corruption (Huther and Shah, 1998; Treisman, 1999; Fisman and Gatti, 2002) by positively testing the hypothesis that smaller countries would be less affected by corruption; they would be able to establish virtuous processes in the public administration and a more efficient monitoring of the government members and politics representatives (Lambsdorff, 2005). As stated above, a third research group has examined the association between institutional quality and corruption (Tanzi and Davoodi, 2001; Lambsdorff and Cornelius, 2000). Particular attention was paid to the relationship between bureaucracy and corruption and to the relationship between the latter and administrative simplification. The impact that reforms of 
recruitment procedures and wage policies in the public administration can have on the increase or decrease of perceived corruption has also been assessed (Evans and Rauch, 2000; van Rijckeghem and Weder, 2001).

With reference to political causes, the relationship between the level of democracy and corruption in a State (Paldam, 2002; Manow, 2005), the link between this criminal conduct and the freedom of the press were delved deeper. For example, through the data provided by Freedom House, Brunetti and Weder (2003) have shown that reforms of the regulatory apparatus aimed at increasing the freedom of the media, in association with a compression of political and economic power in the press and a containment of repressive actions, determine a significant decline in perceived corruption. Persson, Tabellini and Trebbi (2003) have wondered if and how the electoral system adopted in a country could have repercussions on corruption and have shown that electoral systems that prevent a continuous change of candidates are positively associated with the increase in perceived corruption at the national level.

As we can deduce, the hypotheses explained up to now do not seem to derive from modern criminological theories; they mainly focus on the effect that a single independent variable has on the phenomenon, while they neglected the combined effect that most independent variables have on the dependent variable "corruption".

As Sutherland and Cressey suggested (1978; page 112), "a scientific explanation of criminal behavior can be formulated in terms of processes acting when the crime occurs, or in terms of processes acting in the previous history of the author of the crime". In the first case the explanation of crime has a mechanistic situational nature, typical of biology and natural sciences, while in the second case it can be situated in the lines of an historical/evolutionary research.

In the first perspective the objective context provides the opportunity for a specific criminal behavior and is very relevant. Corruption would be the result of opportunities accidentally created, for example, by the organizational environment of the public administration or by particular modes of interaction between public and private subjects. The situational/mechanistic perspective, while paying attention to the objective context of the "corruption" crime, does not exclude the importance of the acting subject, since this is often referred to as a rational actor operating in a logic of costs and benefits, covering both the role of intraneus and extraneus in the corrective agreement (Cameron et al., 2005). Recent accounts report about numerous cases of crimes committed by managers and officials of the Inland Revenue that have shaken both the public opinion and the employees. In this regard, this work aims to study the perception of the phenomenon of corruption within the Inland Revenue. The hypothesis is to confirm studies in literature, identify new proposals and open any research space.

\section{Methods}

This study was made on a total sample of 50 employees of the Inland Revenue, aged between 30 years and 65 years of which 13 females and 37 males. The sample was divided into 4 age groups. The first includes subjects up to 30 years, the second one includes subjects between 31 and 50 years, the third one includes subjects between 51 and 65 years of age and the fourth one includes subjects over 65 (Figure 1).

Interviewed subjects have a level of education that goes from the middle school to another post-graduate degree (Table 1, Figure 2).

\section{Tools}

For the purposes of this research, a questionnaire consisting of 19 items divided as follows was distributed:

- 5 personal data applications (gender, age group, educational qualification, residence and employment);

- 4 cognitive nature questions regarding the anti-corruption activity of the Inland Revenue;

- 6 logical-perceptual type questions on the phenomenon of corruption;

- 4 open questions asking for suggestions based on the gained experience.

The average response time to the questionnaire was approximately 25 minutes in individual mode.

Participation was completely voluntary after explanation of the research design to the subjects involved.

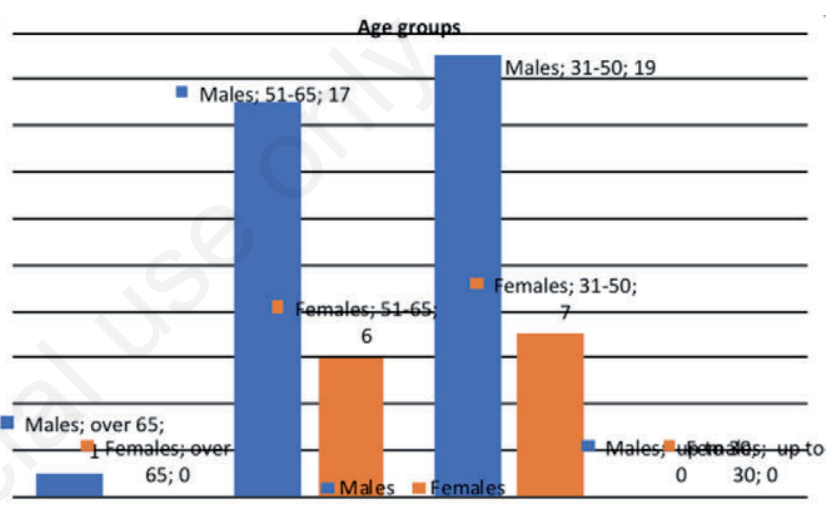

Figure 1. Sample distribution by gender and age group.

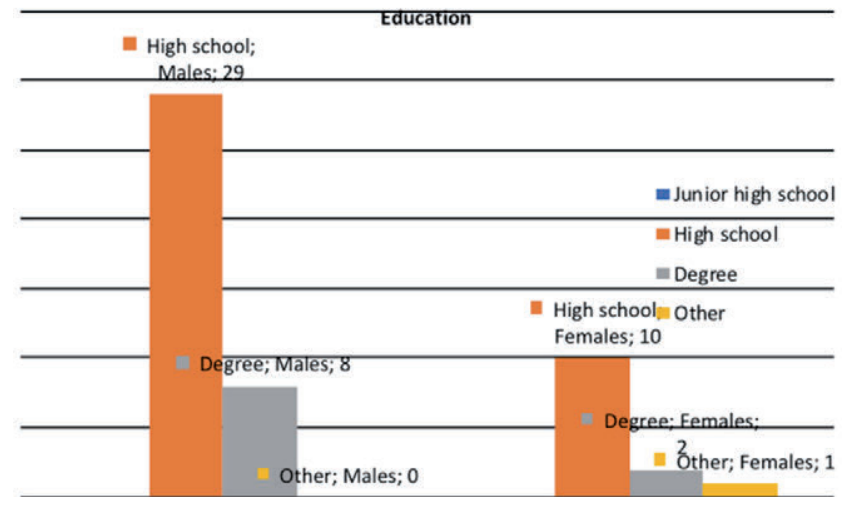

Figure 2. Sample distribution by gender and level of education.

Table 1. Sample distribution by gender and level of education.

\begin{tabular}{lcccc} 
& $\begin{array}{c}\text { Junior } \\
\text { high school }\end{array}$ & $\begin{array}{c}\text { High } \\
\text { school }\end{array}$ & Degree & $\begin{array}{c}\text { Other } \\
\text { post graduate }\end{array}$ \\
Males & 29 & 8 & \\
Females & 10 & 2 & 1 \\
\hline
\end{tabular}




\section{Results}

This study on the perception of corruption within the Inland Revenue showed significant differences depending on the investigated area. Regarding the cognitive examination, $93 \%$ of the interviewees are aware of the widely declared commitment of the anti-corruption Agency and $82 \%$ are aware of a code of conduct and/or an anti-corruption policy explicitly applied to all employees.

Conversely, only $66 \%$ are informed about the channels provided by the Agency, through which employees can report potential policies violations or ask for advice, such as the Whistleblowing program. $42 \%$ of respondents do not know about the existence of a policy that prohibits retaliation against those reporting violations of the rules (Figure 3).

Regarding the logical-perceptual questions about the corruptive phenomenon, the following results emerged: $82 \%$ say that corruption is something different from poor management, a set of unsuitable behavior, incompetence, improvisation and inadequate professionalism; $76 \%$ believe that the estimated savings for public finances would be relevant if the corruption phenomena could be eliminated. No significant data emerged on how much they agreed on a definition of corruption as a "normal" reality pervading the behavior of the Public Administrations, and for $34 \%$, given the size of the corruption, does not believe that an effective system reform is impossible to carry out.

A series of corrective actions were listed and it was found that only $32 \%$ of the subjects consider that accepting, in exchange for money or other fees, to not perform or to inadequately perform (or ask somebody to do that), controls and testing, is the most deplorable corrupting behavior. Two possible initiatives to fight the phenomenon of corruption were proposed, for which it was asked to express the degree of effectiveness: $48 \%$ believe that increasing the purchases through central buying organization (at national, regional, inter-provincial level) has a medium efficacy, and 55\% believe that adopting collective mechanisms to make decisions having direct or indirect relevance on spending has also a medium efficacy. Through the study of the answers received to the request on what could be the possible initiatives to combat the phenomenon, based on the gained experience, emerged requests to strengthen the ethical and moral values of the citizen and of the public employee, stricter controls in many situations such as the verification of consistency between inspections/research, up to the control of the work of the managerial staff, more training and information of the

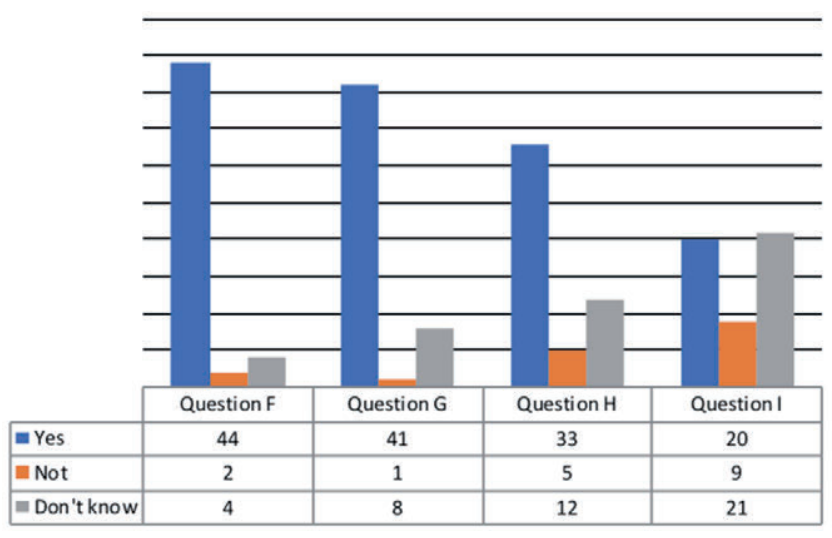

Figure 3. Results of the survey on the Revenue Agency activity. personnel about the consequent transparency and flexibility of the regulations, relevant immediately effective and automatic sanctions (also of economic nature), up to the dismissal, introduction of anticorruption agents in plain clothes, reduction of relations with taxpayers.

\section{Conclusions}

Corruption is a multidimensional process and, as such, can take on different connotations depending on whether the examiner is a jurist or a sociologist, an economist, a criminologist. Giving a quite broad definition of corruption, narrow or not to specific legal cases, is naturally a problem not easy to solve that justifies the existence of various measures of different nature, subjective or perceptual, judicial experiential (complaints, criminal and accounting sentences) as well as relevant gaps often existing between them. In other words, referring to corruption in its widest sense of behavioral deviation from the rules in force in a social reference context, is certainly different than referring to specific legal cases of our legal system. This work was intended to study how the correctional phenomenon is perceived by employees of the Inland Revenue. Knowledge of the commitment in its declared activity of fight against corruption emerged clearly; differently, on the agency that provides the channels through which violations of policies occur, such as the Whistleblowing program, further more than half of the subjects involved in this study described to know it.

Therefore the knowledge resulted in general terms and not in specific terms. Corruption is perceived as a different phenomenon from maladministration, incompetence or lack of professionalism, but it is not properly defined a "normal" reality pervading the behavior of public administrations. An effective reform of the system is hard to achieve because the corruption is perceived inherent in the DNA of the average Italian and therefore no initiatives opposing this phenomenon are undertaken. A limitation of this study is that perceptions can change rapidly without any objective foundation due to political scandals that can condition perception, but which do not reflect the real level of corruption.

They can also be influenced by cultural settings and different conceptions of what is actually meant as a crime of corruption, so the same question can be interpreted in a substantially different way. Respondents' answers can therefore be influenced by the quality and consistency in the formulation of the questions and it is possible that some interviewees do not have the experience and knowledge necessary to express a reliable perception of corruption (Fiorino and Galli, 2013).

The objective context provides the opportunity for a specific criminal behavior; learning and imitation are fundamental in the genesis of criminal behavior (Di Nicola and Zanella, 2011); this emerges from the suggestions on possible improvement actions for the Agency's Corruption Prevention plan. Personnel turnover, professional training on the culture of non-corruption, implementation and enforcement of current regulations and strengthening of controls, as well as an improvement of employees' professionalism and consequent salaries adjustment, role/task rotation for managerial staff and others staff members, are some examples. Given the emerged data we can consider that this study confirms what is already known in the literature. Corruption is the result of contacts with criminal models (patterns) and the removal of anti-criminal models (patterns), as each individual assimilates the culture, even entrepreneurial, that surrounds him (Sutherland and Cressey, 1978, p. 115). If indeed the models that surround us and learning due to daily contacts are among the drivers of corrupt 
behavior, then we better understand why in our country is difficult to reverse the route (Di Nicola and Zanella, 2011). A shared solution lies in the cultural people education, in the school and in the family as preventive agent.

\section{References}

Ades A, Di Tella R. Rents, competition, and corruption. Am Econ Rev 1991;89:982-941.

Ades A, Di Tella R. Competition and corruption. Draft Paper, Keble College, Oxford University: 1995.

Adsera A, Boix C, Payne M. Are you being served? Political accountability and quality of government. InterAmerican Development Bank Research Department Working Paper 438: 2000.

Alibrandi L, Corso P, (a cura di). Codice penale e di procedura penale e leggi complementari. Piacenza: 2017.

Benson GCS, et al. Political corruption in America. Lexington, MA; DC Heath: 1978.

Brunetti A, Weder B. A free press is bad news for corruption. J Public Econ 2003;87:1801-24.

Cameron L, Chaudhuri A, Erkal N, Gangdharan L. Bribery and Public Procurements: an Experimental Study. Working paper, MPI Jena: 2005.

Della Porta, Vannucci. Mani impunite. Vecchia e nuova corruzione in Italia. Roma 2007.

Di Nicola A. Dieci anni di lotta alla corruzione in Italia. Bologna 2003.

Di Nicola A, Zanella M. Teorie criminologiche e corruzione. Uno studio esplicativo in ambito internazionale. Rassegna Italiana di Criminologia, 2011;2:37-44.

Evans PB, Rauch JE. Bureaucratic structures and economic performance in less developed countries. J Public Econ 2000;75:49-71.

Fiorino N, Galli E. La corruzione in Italia. Roma: 2013.

Fisman R, Gatti R. Decentralization and corruption: Evidence cross countries. J Public Econ 2002;83:325-45.

Gerring J, Thacker S. Political institutions and governance: Pluralism versus centralism. Br J Political Sci 2005;34:295-303.

Karstedt S. Comparing cultures, comparing crime: Challenges,

Correspondence: Maurizio Longhi.

E-mail: m.longhi@studenti.unitelmasapienza.it

Key words: Corruption, perception.

Parole chiave: Corruzione, percezione.

Palabras clave: Corrupción, percepción.

Received for publication: 30 November 2017.

Revision received: 25 December 2017.

Accepted for publication: 30 March 2018.

This article is distributed under the terms of the Creative Commons Attribution Noncommercial License (by-nc 4.0) which permits any noncommercial use, distribution, and reproduction in any medium, provided the original author(s) and source are credited.

CCopyright M. Longhi, 2018

Licensee PAGEPress, Italy

Rivista di Psicopatologia Forense, Medicina Legale, Criminologia

2018; $23: 26$

doi: $10.4081 /$ psyco. 2018.26 prospects and problems for a global criminology. Crime Law Social Change, 2001;36:285-308.

Huther J, Shah A. A simple measure of good governance and its application to the debate on the appropriate level of fiscal decentralization. World Bank Working Paper Series: 1894 1998.

Lambsdorff GJ. Consequences and causes of corruption - What do we know from a cross-section of countries? Working Paper, University of Passau: 2005.

La Porta R, Lopez-De-Silanes F, Shleifer A, Vishny RW. Trust in large organisations. Am Econ Rev 1997;137:333-8.

Manow P. Politische Korruption und politischer Wettbewerb: Probleme der Quantitativen Analyse. Dimensionen politischer Korruption, Sonderheft der Politischen Vierteljahresschrift. VS Verlag für Sozialwissenschaften, Wiesbaden: 2005.

Merton RK. The latent functions of the machine. In: Urban bosses, machines and progressive reformers (M.S. Bruce, editor), Lexington: 1972.

Nye JS. Corruption and political development: A cost-benefit analysis. Am Polit Sci Rev 1967;2.

Paldam M. The cross-country pattern of corruption: Economics, culture and the seesaw dynamics. Eur J Polit Econ 2002; $18: 215-40$

Persson T, Tabellini G, Trebbi F. Electoral rules and corruption. J Eur Econ Ass 2003;1:958-89.

Rivas MF. An experiment on corruption and gender. Working paper, 08/06. University of Granada: 2006.

Rose-Ackerman S. Corruption and government: Causes, consequences, and reform, Cambridge University Press: 1999.

Savona EU, Mezzanotte L. La corruzione in Europa. Roma: 1998.

Scott JC. Comparative political corruption. Englewood Cliffs, NJ: 1972.

Sutherland EH. Il crimine dei colletti bianchi. Milano: 1987.

Sutherland EH, Cressey DR. Criminologia. Milano: 1996.

Tabellini G. Political economics: Explaining economic policy. Cambridge, MA; MIT Press: 2000.

Tanzi V, Davoodi H. Corruption, public investment, and growth. International Monetary Fund Working Paper 97/139, 1997.

Treisman D. Decentralization and corruption: Why are federal states perceived to be more corrupt. Annual. Meeting of the American Political Science Association, Atlanta, 1999.

Treisman D. The causes of corruption: a cross-national study. J Public Econ 2000;76:399-457.

van Rijckeghem C, Weder B. Bureaucratic corruption and the rate of temptation: Do wages in the civil service affect corruption, and by how much? J Dev Econ 2001;65:307-31. 